\title{
'Becoming human again': Exploring connections between nature and recovery from stress and post-traumatic distress
}

\author{
Stephanie Westlund \\ E-mail: steph.westlund@gmail.com; Website: http://www.fieldexercises.com/
}

Received 8 May 2013

Accepted 6 January 2014

\begin{abstract}
.
BACKGROUND: Many military veterans are seeking ways beyond conventional treatments to manage their stress injuries. An increasing number is turning to nature, including hiking and fishing, farming and gardening, and building relationships with dogs or horses. Many continue to benefit from medication and therapy, but find that nature provides an additional measure of support, relief and healing in their lives.

OBJECTIVE: This paper examines reciprocal interactions between humans and nature during post-conflict recovery, with a focus on the experiences of four North American veterans who regard their personal recovery from stressful and traumatic military experiences as intimately tied to their nature experiences.

METHODS: Experience-centered narrative inquiry often sheds light on details and experiences concealed or overlooked by other research paradigms. In-depth interviews about post-military experiences with recovery were conducted with four veterans who suffer from stress and/or post-traumatic distress; these experiences are further illuminated by supporting interviews, and theories and praxis in ecopsychology, cognitive science, neuroscience, biophilia, and ecological intelligence.

RESULTS: Through exploring themes of sensory experience, safety, sense of purpose, and renewed relationships, this research gives space to former soldiers' stories of experience and to their individual realizations that their embodied interconnections with nature provide alternative experiences to their military training and combat exposure.

CONCLUSION: The veterans' experiences with nature and recovery are pointing towards an avenue of recovery that is little acknowledged in the mainstream literature and praxis, but deserving of attention.
\end{abstract}

Keywords: Military veterans, ecopsychology, combat exposure, narrative inquiry

\section{Introduction}

The documentary Shake Hands with the Devil: The Journey of Roméo Dallaire is a devastating account of the United Nations Assistance Mission for Rwanda's failure to prevent the Rwandan genocide [1]. In the years since the Mission, Lieutenant General (retired) Roméo Dallaire, who was commander of the Mission, has spoken candidly about his post-traumatic struggles. Approximately an hour into the film, Dallaire and his wife, Élizabeth, stand holding hands atop a lush ter- raced hillside in Kinihira, Rwanda - a place he visited often during the Mission - and he tells her, " $C$ 'est ici que j'ai redevenu humain." (English translation: "It's here that I became human again.") Later, Dallaire returns with the filmmakers to that hilltop and remarks, "I want to show you where in all this I could find myself. I could find the solace and be one with my soul, with my heart, with my being."

Morris, meanwhile, is a young man and former child soldier from the Liberian and Sierra Leonean civil wars [2]. After many years, Morris escaped to the 
Buduburam Refugee Camp in Ghana following a realization that his fighting had turned him into an empty shell and that he no longer felt human. As part of his personal healing, and to give back to the refugee community, Morris assembled approximately 200 other former child soldiers living in the camp, and the youngsters built a farm to grow and harvest fruits and vegetables. The healing and recovery process for these young people is anything but easy. All of them carry the stigma of their former roles as combatants, and many others in the community continue to see them as rapists and murderers. However, the youngsters find comfort both in their relationships with one another and in cultivating new life together [2]. And they carry hope that others will eventually see that they have the power to change, to do good, and will one day accept them into the larger community.

Extending examples such as those of Lt. Gen. Dallaire and former child soldier Morris, this paper examines reciprocal interactions between humans and nature during post-military recovery, with a focus on the experience-centered narratives of four North American veterans who regard their recovery from traumatic military experiences as intimately tied to their nature experiences. Most of the veterans came accidentally to the discovery that they felt better in the outdoors, after which they purposefully sought out more such experiences. Through exploring themes of sensory experience, safety, sense of purpose, and renewed relationships, this paper explores recovery from conflict as embedded in and supported by more-than-human nature. ${ }^{1}$ In this context, the term "recovery" does not suggest erasing or forgetting the stressful and/or traumatic experiences that the veterans have lived through, but

\footnotetext{
${ }^{1}$ Rather than 'non-human nature,' the author prefers David Abram's [53] term 'more-than-human nature,' which accepts the radical ecological dependencies and relationships within the larger family of things. For example, if a tree defined everything other than itself as 'non-tree,' the 'tree' world becomes very narrow. The 'nontree' world would include the soil in which the tree grows, insects that pollinate the tree's flowers, the birds and winds and squirrels that disperse the tree's seeds, the rain and snow waters that help the tree grow, the animals whose excrement and decomposing bodies provide essential nutrients to the tree's roots, the human who sits in the tree's shade on a hot summer day and breathes out carbon dioxide to give the tree breath, the insects and worms that decompose the tree once its life ends so that it may provide life to other trees, and so much more. By changing 'non-tree' to 'more-than-tree,' it is possible to conceptualize the tree as being in ecological relationship with all these other beings that, while distinct, are important in the tree's lifecycle, and without which, the tree would not live. Similarly, the term more-than-human accounts for the complex ecological dependencies that form the basis of human life.
}

rather, that these events provide the context of their present living, and it is from there that they seek ways to continue living their lives.

\subsection{Theoretical perspectives}

In the 1960s, psychoanalyst Harold Searles argued that most studies in psychoanalysis have been limited to understanding inter- and intra-personal processes in personality development. The literature considered nature to be irrelevant, "as though human life were lived out in a vacuum - as though the human race were alone in the universe, pursuing individual and collective destinies in a homogeneous matrix of nothingness, a background devoid of form, color, and substance" [3, p. 3]. In response to these studies, and drawing on his work with schizophrenic patients, Searles began articulating his vision that nature is of primary importance to the human psyche, since the human personality matures within a "total matrix" comprising "predominantly nonhuman elements - trees, clouds, stars, landscapes, buildings, and so on ad infinitum" [3, p. 53]. Accordingly, he observed that when humans ignore the connections between their psyches and nature, it endangers their psychological well-being.

Meanwhile, social historian Theodore Roszak has observed that at one time, "all psychologies were 'ecopsychologies.' Those who sought to heal the soul took it for granted that human nature is densely embedded in the world we share with animal, vegetable, mineral, and all the unseen powers of the cosmos" [4, p. 14]. Indeed, connections between nature experiences and human health have been accepted by poets, sages, and indigenous peoples, amongst others, for thousands of years. Ancient Greek healing places and temples were purposefully located on hilltops in the countryside with views of the ocean, around the same time that Taoists in China were building greenhouses and cultivating gardens as part of their approach for maintaining health and wellbeing [5,6]. Chinese mystics often escaped the activity and clamor of towns for the countryside, where they sought to find and restore their souls, while the Christian Bible tells numerous stories of holy men who retreated to the desert to have contact with God [7].

In the Middle Ages, gardens were deemed an important facet of human healing, particularly in monastery settings [8]. During the Victorian era, gardens were often found in hospitals [9]. And beginning in the nineteenth century, French churches advocated community gardens as a way to improve the circumstances 
of the working poor [10]. Similarly, the Quakers' Friends Hospital in Pennsylvania treated patients suffering from mental illness with gardening and walks in the surrounding lands [5]. Today, however, human health tends to be placed solely in the urban-industrial context of the individual, separate human being [11, 12]. Within this context, clinical psychology and psychotherapy are viewed as the best methods for helping struggling individuals, and relationships within the wider world of nature are viewed as irrelevant [13].

In contrast with modern psychology and psychotherapy, ecopsychology explores the intertwining between healthy ecosystems and human health conditions $[4$, $12,14,15]$, and is described as an intervention aimed at "the regaining of lost world-relations and lifemeanings" [12, p. 187]. Ecopsychology works to locate the human psyche within what Larry Robinson calls "the complex, interconnected web of humans, animals, plants, microbes, rocks, oceans, and stars" [16, p. 26]. Indeed, ecopsychologists regard urban-industrial society to be at the root of much of the suffering - grief, despair, and anxiety - in modern times. Western culture, they say, leads to estrangement from nature by dismissing ecological instincts deeply rooted in the human psyche. The most important contribution of ecopsychology to this project is its rejection of the notion that humans are separate from (and higher than) nature and the idea that "inside" is disconnected from "outside." In particular, ecopsychologists' interests lie in envisioning and achieving a fulfilling, life-nurturing, and sustaining relationship with what Fisher calls "the world of nature" [12, p. 33].

Meanwhile parallel theories and research are also arising in various other traditions. For example, biologist E.O. Wilson has observed that human beings have an affinity for all life forms, which expresses a deeprooted genetic and biological need $[17,18]$. For Wilson, our humanity itself is defined by our interactions and kinship with other organisms. Author and psychologist Daniel Goleman [19], perhaps best known for his work on emotional intelligence, which draws on Gardner's [20] theory of multiple intelligences, has recently promoted what he calls "ecological intelligence": "our ability to adapt to our ecological niche" [19, p. 43]. Neuroscientist Kelly Lambert's research shows that human bodies, senses, and emotions were crucial to human evolution and becoming, but that people all over the world today are engaging almost exclusively in cognitive tasks, which leave the body behind. Her overall contention is that "the environment around us is a critical variable in determining the severity of our stress responses in different situations" [21, p. 243]. And cognitive science draws on the human body as a "lived text" and establishes the interconnectedness of all things, revealing that it is embodied interactions in the world that offer the grounds for human perception [22]. Drawing on research in cognitive science, linguist George Lakoff and philosopher Mark Johnson argue that "our body is intimately tied to what we walk on, sit on, touch, taste, smell, see, breathe, and move within. Our corporeality is part of the corporeality of the world" [22, p. 565]. Further, nature is not an "other" or an assortment of objects we might stumble upon. It is the basis of our being, "the locus of our existence and identity. We cannot and do not exist apart from it" [22, p. 566].

Most importantly in the context of this paper, while the theories and research described above come from widely varying perspectives, they are connected by an agreement that the human brain evolved in complex environments, in which human survival depended on constant interaction with other creatures and all of the sentient earth. Moreover, all assert that while often repressed in modern times and culture, deep ecological instincts continue to be rooted in the human psyche. Humans today, despite our technological prowess and increasingly urban lifestyles, are genetically the same as our hunter-gatherer ancestors [5,18,21]. Indeed, anthropologist Euclid Smith likens the rate of biological evolution to "the speed of a glacier in comparison to the rate of change in our culture" [23, p. 13].

\subsection{Terminology and post-traumatic distress}

Various terms have described the suffering that comes with the invisible wounds of war, including expressions such as estar roto, a Spanish term from the seventeenth century which literally means "to be broken" [24, p. 99], as well as "soldier's heart," "shell shock," "combat fatigue," and "battle fatigue" [25-28]. All convey powerful images of shock and distress compared with today's more sterile term "post-traumatic stress disorder" (PTSD), which simply becomes an abbreviation or organizing category on a medical report [29]. In an interview, research participant and veteran Shepherd Bliss reflected, "I don't like the term PTSD because ... the problem is, then you see yourself as a disorder. Nobody is a disorder."

Indeed, Jungian psychologist James Hillman brings attention to the "the inhuman stress of war" and argues that "the very idea that human agony can be named a 'stress syndrome' is inhuman, imagining a man as a 
machine part, a cog in a military wheel" [29, p. 62]. Because this research explores the narratives of veterans who have found ways of easing their suffering outside the medical model, it also requires a break with the language of the medical model. This paper therefore uses the term "post-traumatic distress" as suggested by Andy Fisher [30].

\subsection{Experience-centered narrative inquiry}

Trauma and distress are experienced subjectively and are embodied in various ways, including through "physical illness, disability, addiction and pain" [31, p. 11]. It may be easy to examine specific trauma incidents underlying some veterans' distress, but it is more difficult to understand the experience and the meaning the distress has in their daily lives, at the unexpected swells of anger or the unpredictable nature of flashbacks, for example, that impede each veteran from living as he or she might wish. Narrative inquiry makes it possible to shed light on details and experiences often concealed or overlooked by other research paradigms. Similar to phenomenology, rather than being concerned with quantitative criteria such as validity and reliability, narrative inquiry aims at understanding the phenomenon of each person's individual experience [32]. Experts note that a crucial aspect of narrative inquiry is that it provides space for individuals to tell their stories [32]. The narratives comprise the research data and allow researchers to explore the topic in complex and multiple ways, and all learning arises out of the stories [33,34]. In the case of veterans suffering from stress and post-traumatic distress from their military training and service, it is not enough to understand their symptoms causally. Accordingly, this research draws on experiential accounts and reflections of veterans' lived experiences to illuminate the importance of human senses, and to value their embodied contact with the world around them.

In experience-centered narrative research, one important way of exploring a particular phenomenon is to interview several people about the same experience [35]. This research brings to the forefront the stories of veterans suffering from stress or post-traumatic distress, who have tied their coping and recovery from traumatic military experiences to their lived experiences within nature. Andy Fisher observes that the body - not the mind - "is always implying further steps of living that will carry our experiencing forward" [30, p. 165]. And in this research, all the veterans, and many of the supporting interviewees, reflected that their rela- tionship with the natural world came before conscious reflection and theorizing. They each realized that they were feeling better, and, only following that realization, did they reflect on where and in what context they felt better - that is, namely in the company of morethan-human nature.

Participants were selected via a convenience and network sample. The author first became aware of three of the veterans' stories by reading about their experiences in news articles and research books, while the fourth veteran was introduced to her by another veteran. The author conducted a total of eleven unstructured, open-ended interviews; however, interviews with the four veterans form the core focus of this paper. In the case of the Canadian Veteran Adventure Foundation (CVAF), the author also interviewed all members of the board of directors. Two additional people were interviewed to illuminate and complement the veterans' stories: Kurt Hoelting, who runs a sea-kayaking outfitter-guide business and teaches Mindfulness-Based Stress Reduction to veterans at the Seattle VA Hospital; and Andy Fisher, a psychotherapist and leading scholar within the field of ecopsychology. The veteran interviews centered on how each came to realize that nature was important in his life and his experiences of interacting with nature during his ongoing recovery. Open-ended questions allowed each interview to follow a trajectory mainly set by the veteran. Each participant was provided with a copy of his interview transcript for review and approval. Using a process of inductive analysis, the author read and reread each interview transcript many times, to draw out and code common themes, ideas and patterns within the veterans' narratives.

It is important to acknowledge the gender and ethnicity imbalances in this research, although the author is unsure whether these imbalances affect the findings. Because of the sampling method used, the author did not encounter the stories of either female veterans or ethnic minorities emphasizing their experiences of recovery and nature. In addition, three of the veterans served in the Canadian Forces, which has traditionally focused its recruitment efforts on young men, aged 1724 , living in rural areas or smaller urban centers with populations below 100,000 [36]. The rural population in Canada tends to be of European descent, as does the population of smaller cities and towns across the country. Typical recruits have thus tended to be young white men, often with family histories of serving in the military. Future research on this topic would ideally include additional narratives from both female veterans and ethnic minorities. 


\section{Analysis}

Andy Fisher draws attention to the ways that "our experience is always directing us toward some sort of contact with the world and the world itself calls forth our experience" [12, p. 26]. The veterans' subjective experiences studied in this paper vary widely, as do the causes of their stress and/or post-traumatic distress, and their interactions with/in the natural world. However, when their stories are read together, their experiences inform one another and reveal commonalities and connections.

All four veterans are white males, ranging in age from early 30 s to mid-60s. Three of the participants asked that their real names be used, while one (whom the author calls Tim Normann) requested a pseudonym. All of them joined the military as young men, with three serving in the Canadian Forces, while one served in the United States Army. Two saw active duty as either a peacekeeper or combat soldier, while the other two completed training but were never deployed. All four men relay the ways in which their lives were changed by their military training and/or service and describe suffering from stress, hypervigilance, and/or distress resulting from their military experiences, although only some have been medically diagnosed as suffering from post-traumatic symptoms.

Christian McEachern, now in his 40s, served in the Canadian military for 14 years. He was a peacekeeper in the former Yugoslavia and Uganda and was officially diagnosed with post-traumatic stress disorder in 1998. A few years after leaving the Canadian Forces with an honorable discharge in 2001, Christian began studying for a Bachelor of Applied Ecotourism and Outdoor Leadership at Mount Royal College (now Mount Royal University) in Calgary, Alberta. After receiving a slew of veteran support services, including counselling and medication, Christian describes how, as he sat on the banks of a river in 2005, he finally felt "at peace with life for a moment." In 2006, Christian founded the Canadian Veteran Adventure Foundation (CVAF), which he envisioned would provide another tier in the care and treatment of Canadian Forces veterans suffering from post-traumatic distress through outdoor programming and adventure training. ${ }^{2}$

Tim Normann served as a member of the Canadian infantry in Afghanistan in 2004 and 2005. Upon returning home, Tim felt a clear need to go climb-

\footnotetext{
${ }^{2}$ Unfortunately, the CVAF disbanded in July 2011 due to a lack of funding.
}

ing in the mountains, something he had done since he was a teenager. Now in his early 30 s, young and fit, Tim is the perfect picture of an outdoorsman in Canmore, Alberta, a mountain town where he and his wife moved shortly after releasing voluntarily from the Armed Forces. His post-military dream was to become a full-time alpinist and to have a job on the side to sustain that lifestyle. Tim says he does not suffer from post-traumatic distress but describes himself as "changed" by his military service, and suffers from stress reactions and episodes of hypervigilance. As he describes, "There's something about the outdoors that's helped me move on from my service and look inside. And to become - I wouldn't say whole again, but just not so military, if you will."

In 1968, at age 19, while training to become a Canadian peacekeeper in Vietnam, Gord Cousins was critically injured in a training accident. He lost all the fingers on his right hand, and the hearing in his right ear was severely damaged. In addition, a 21-inch-long piece of shrapnel pierced his right collar bone in two places, opened the top of his right lung, and stopped within a quarter of an inch of his spine. In addition to his physical injuries, Gord suspects that he also suffered from post-traumatic distress as a result of the accident. He recalls his experiences of tremendous anger, and what he refers to as "a killer instinct coming out," despite never having been on the front lines of combat. From his childhood through the present, Gord has spent time in nature, and he believes this was critical as he adjusted to his changed life circumstances. A tall, slim man now in his early 60s with short greying hair and a friendly smile, Gord emphasizes the embodied aspects of spending time in nature, and the ways that human experience itself takes on a different rhythm in the natural world that contrasts sharply with the constant demands of modern urban life.

Shepherd Bliss was born into a long-time military family, and he never questioned that his destiny was also to be in the military. After being commissioned into the U.S. Army and having requested a post in Vietnam, however, he left the military after hearing Martin Luther King, Jr., speak at a peace rally. Soon thereafter, he went on to earn a doctorate from the University of Chicago School of Divinity. He also spent time in Chile during the Allende regime in the early 1970s. He left Chile shortly before Augusto Pinochet's military coup in 1973; however, Shepherd's fiancée was tortured there, and his best friend was tortured and killed. These various traumas from his military upbringing, his own military service, and his experiences 
in Chile caused him to suffer from post-traumatic distress - in particular from what Shepherd terms "sound trauma," in which he is exceptionally sensitive to noise. In his 40s, he bought a farm in Sonoma County, California, and today Shepherd credits farming as one of the most beneficial activities in managing his trauma experiences. Farming, he says, redirects energy to the plants and animals, and there is (or can be) limited contact with other human beings. He also observes that the act of growing food for other people has been important in his recovery. Now in his late-60s, Shepherd reflects, "Life is good. It hasn't always been that way."

\subsection{Sensory experience in the more-than-human world}

The veterans interviewed often highlighted how the phenomenological experience of trauma is the opposite of feeling present. Through flashbacks and panic attacks, sufferers are easily drawn into the past which seems to be happening in the present. Connecting with more-than-human nature, meanwhile, provided each veteran with an alternate sensory experience, in which he described increased mindfulness and a feeling of being more fully present in the world. While it is important not to overstate an urban/nature dichotomy [37], many of the veterans remarked on the significance of places 'away' from urban environments. These places took them away from the pressures of everyday life and modern technologies, opening space for their energies to dissipate and to explore their wounds and find stillness.

Each veteran described how his embodied experiences in the natural world turned his attention back toward the ways that nature is regulated by cycles and seasons, by birth and death, by relations between animals and plants, and so on. For example, Tim Normann shared how being in nature helps him to put life and his experiences into perspective:

If I'm not mindful about what's going on with my environment and with me when I'm in the outdoors, especially in the mountain environment, I could be at risk. I could be walking right into a dangerous situation. So for me it definitely increases my sense of awareness. It brings down a lot of the barriers to being fully present. You leave the watch at home. You leave technology behind and you get a chance to slow down . . . you're on a different clock when you're outside.
After moving to Calgary in the 1970s, Gord Cousins spent a lot of time alone in the mountains, and he observed that spending time in nature leads him to feel more "fulfilled, in control, you're responsive to the things around you ... perhaps a better way of saying it, you're more aware of the things around you rather than having to respond to every circumstance." As Gord spoke, he emphasized the physical/embodied aspects of spending time in nature, and that rather than going by the rhythm of urban lifestyle or the demands of other people, nature presents its own rhythm. Gord explained, "Day turns to night, you stop. Light comes in the morning, you get up. There's a rhythm that's much different than somebody yelling at you to do this or that. Or you've got to punch a clock at a certain time."

When he bought his own farm, Shepherd Bliss initially sought to recreate some of his childhood experiences on his uncle and aunt's Iowa farm. The sensory experience available through farming and working the land became clear in Shepherd's description of using only hand tools, such as scythes and machetes, on his farm. He pulls weeds by hand, and enjoys hearing the wind blowing through the nearby bamboo, as well as watching and listening to his chickens dance and talk to one another and dig in the dirt. Indeed, he credits farming as one of the most beneficial activities in his learning to live with and move towards recovery from his trauma experiences. (The other beneficial activity is his continued participation in the Veterans' Writing Group led by writer and poet and peace activist Maxine Hong Kingston) [38,39]. Farming, in many ways, is the opposite of conventional therapy. It is the opposite of a "talking cure;" it is, Shepherd explains, "nottalking" [38].

Pointing to other ways that nature opens possibilities for mindfulness, Shepherd also described his and other members of the Veterans Writing Group's slow walking meditations beneath the canopy of the giant eucalyptus forest, led by Kingston. Shepherd observed how difficult the walking meditations were for veterans who were used to "walking point" in Vietnam, which means they were first in line on their foot patrol into the jungle, and knew they would be the first to draw enemy fire. "But after a while, you really get into the wonderment of knowing that you are protected and there is no threat, so you walk it out. Your body sees the land, not as a place to be scorched with napalm or that's concealing somebody who could hurt you, but it's welcoming. And so you begin to transform that."

After years of undergoing treatment for his posttraumatic distress through the medical system, Chris- 
tian McEachern shared how one of his first moments of feeling "at peace with life" in his post-military experience came while he sat on the banks of a river. Moreover, in recalling a 2009 weekend trip offered for veterans by his organization, the Canadian Veteran Adventure Foundation (CVAF), Christian described the palpable differences in the other veterans after just one morning of rafting on the Bow River: "You could just see the guys melting, starting to relax and smile." Similarly, Ian Sherrington, a CVAF board member and associate professor at Mount Royal University who was also on the trip, commented how over the weekend, he could "see the life flowing back into [the veterans]." Even psychiatrist Greg Passey, who participated in the weekend's activities, observed in his comments on the CVAF's website the "calming effect and sense of peace" instilled for many of the veterans [40].

In all of these experiences, it seems that through their sensory interactions with the elements, with the earth, air, water, and with more-than-human beings, the veterans began to transform their experiences. Their encounters with/in the natural world provided alternative experiences to those manifested during their stress reactions and/or other symptoms associated with stress and/or post-traumatic distress. As Andy Fisher observes, "against the historical interiorizing of the psyche, our bodies call for a re-establishment of safe and loving world-relations" [30, p. 167]. Further, he writes that "the voice of traumatic pain in our own time is thus asking for a more loving, human, spiritualized world. That's the body talking" [ibid.]. The body speaks clearly in each of the veterans' narratives.

\subsection{Safety in nature}

Many veterans, and particularly those suffering from the effects of stress and post-traumatic distress, describe not feeling safe once they return home to Canada or the United States. Their wartime and/or peacekeeping experiences are forever imprinted on their psyche and body and become the new vantage from which they experience the world. Many veterans then feel constantly threatened by the people and situations they encounter in daily life at home.

In his interview, Christian McEachern described "taking a knee" in Safeway during a panic attack. Meanwhile, Tim Normann shared the story of how late one night, he rushed out of his condo with a baton and bear spray towards the occupants of a car who were honking their horn incessantly. The occupants drove off before an altercation could occur, but Tim was baffled by his reaction.
When we do not feel safe, our body becomes tense, on constant alert. The heart might pound as increased adrenaline courses through the veins, and one may react in ways that are surprising, as in Christian and Tim's examples. Similarly, the feeling of safety is also something experienced in the body.

Tracing a word's etymology sometimes reveals forgotten meanings embedded in a word, and an etymological examination of the term 'safe' reveals important insights and connections. Its Latin root salvus, which means 'uninjured, healthy, safe,' is related to the Latin salus, meaning 'good health,' and saluber meaning 'healthful.' Furthermore, all of these words share an ancestral tie to the root sol, from the ProtoIndo-European ancestral language, meaning 'whole,' and are thought to be connected to, among other words, the Sanskrit sarvah, 'uninjured, intact, whole,' and the Greek holos, 'whole' [41]. Therefore, a sense of safety refers not only to an experience of freedom from danger or lacking injury, but also a state of good health and a sense of wholeness.

Accordingly, an important connection amongst the veterans' stories is the way each describes finding safety in more-than-human nature. For example, Tim Normann observed the difference in the quality of the conversations that occur between veterans in outdoor spaces compared to indoor spaces. He reflected that in his experience, spending time in nature "allowed us [veterans] to create some space outside that essentially is a safe space for us to just talk about [experiences of post-combat stress reactions]. I've spent a lot of time with veterans in other situations ... but not being outdoors, and the same types of conversations don't happen."

Christian McEachern reflected on the notions of tension and negative energy and the ways that it is much easier and feels safer for him to talk about military incidents and events to a friend or another veteran while grooming horses together. He contrasted this with his experiences of indoor group therapy sessions, after which he often found that his agitation and anger had increased rather than decreased. And as he came to notice the ways that spending time outdoors eases his suffering, Christian began to ask why therapy sessions could not be held outside, perhaps around a campfire after a day of canoeing. His own experiences support his belief that "with being outside, that [negative] energy has a place to go."

Gord Cousins observed that from his childhood through his rehabilitation and even today, spending time in nature has helped him to adjust to changing life 
circumstances. He shared his struggles with frustration and anger during the 1980s and suggested that perhaps there is a link to the fact that, when he had young children in the 1980s, he wasn't able to keep up his active outdoor lifestyle. In the 1990s, as he once again became active in the outdoors through a new role with the local Cadet corps, Gord described how his angry outbursts and waking periods in the night began to subside.

Shepherd Bliss shared that the main benefits of farming lie in how it redirects energy to the plants and animals. He has written about how his relationships with other people have improved because of his work on the farm [38]. During his interview, the notion of safety came up in the ways that his farm provides possibilities for new relationships with children. Even though he has no children of his own, Shepherd described himself as "newly captured by the grandfather archetype" and observed that his interactions with the children who come to his farm provide important and "safe" contact, since his post-traumatic distress has made maintaining relationships difficult. Furthermore, Shepherd reflected that the farm - the earth, grass, winds, leaves, flowers - provides safety for other veterans who spend time there. Shepherd has noticed that the veterans sometimes open up around a picnic table in ways they might not in a clinical setting. In his experience, "there's something about the healing power of the regenerative earth, the grass, the leaves, the flowers, the bees, whatever wanders in, the ants while they're doing their work, the honey bees that don't sting." And in this context, Christian McEachern's question "why does counselling and group therapy have to be in the office all the time?" becomes very important.

It seems that each veteran is describing the ways that the natural world calls forth his experience, his negative energy, his suffering. The more-than-human world is big enough to hold his stress and distress. Drawing on attachment theory, Andy Fisher observed during his interview that the more-than-human world often becomes a secure base for children in middle childhood: "We learn to rely on the places where we are and our knowledge of them to ground ourselves and to feel a sense of security in the world." Further, he suggested that this security is something we can return to in adulthood. Indeed, understood within an ecopsychological framework, the experiences and safety the veterans are describing are demonstrating a "life-forwarding directionality." Tim Normann observed that rather than having expectations about what needs to happen next, nature "meets you where you're at." And elsewhere,
Fisher contends that "bearing pain is always a matter of placing it in a larger context so that it both loses its overwhelming power and is given the space it needs to move" [12, p.192]. For each of the veterans, it seems that more-than-human nature calls forth his suffering and provides this space to move. And perhaps, at its base, the security each finds in nature lends to the sense of good health and wholeness held within the etymology of the word "safe."

\subsection{A renewed sense of purpose through experiences in the natural world}

As each veteran spent time in nature, he also regained lost confidence, developed a sense of purpose and meaning outside the institutional context of the military, and realized that he had a valuable role to play in his community. In exploring the issues of lost confidence and lost purpose, it is helpful to consider the military, especially venues such as military academies, basic training (or "boot camp"), and missions away from home, within the realm of what sociologist Erving Goffman names a "total institution" [42]. Members learn very specific ways of being and acting in the institution's context, which provides an all-encompassing experience for those working and living inside it. Joshua Goldstein reflects that the key goal of basic training is to implant in soldiers a deep sense of discipline and an "instinct to obey orders" [43, p. 203]. This instinct was conveyed in Christian McEachern's observation that "they train you so hard that it's instinct after a while." Similarly, it is found in Tim Normann's comment that "you're trained to respond to situations in a certain way ... [and] the ideal response in a stressful, dangerous situation is ... with maximum speed, aggression, and violence to take out the enemy or the threat." It also becomes clear in Shepherd Bliss's description of being born into and raised in a long-time military family and growing up on military bases. "Demilitarizing myself has been fortysome years," he commented. "I was militarized the first twenty, twenty-five." In addition, militarization, as Goldstein observes, involves training and disciplining soldiers to suppress their emotions, particularly fear and grief, since "cultural norms [in the military] force men to endure trauma and master fear, in order to claim the status of "manhood"' [43, p. 264].

This awareness of the military as an institution that completely orients the lives, bodies, and emotions of soldiers is helpful in understanding the sense of loss and lack of purpose that many veterans ex- 
perience upon leaving the military. Lost confidence is also common for veterans suffering from posttraumatic distress, because flashbacks and panic attacks are unpredictable. After all, panic attacks and post-traumatic suffering might be viewed as the opposite of the "archetypical (ideal) military member" who is "a strong, capable, courageous man who is willing to give up his life to protect the freedoms and way of life of western citizens" [44, p. 1]. Experiencing a flashback and becoming incapacitated in an everyday life situation, such as shopping at a grocery store, can lead sufferers to increasingly avoid such situations or even to withdraw and disengage from their community. Accordingly, Christian McEachern observed that a common sentiment amongst veterans is that their flashbacks, panic attacks, and anxiety make them feel "stupid," and they are always worried about "looking stupider than they already feel."

Christian, too, experienced lost confidence and lack of purpose after being discharged from the military. And it was a number of years after leaving the military, as he participated in the outdoor activities provided through the Bachelor of Applied Ecotourism and Outdoor Leadership at Mount Royal College in Calgary, that Christian describes a moment of sudden insight: "It was almost as if I realized I could still do it." As his confidence in his own abilities returned, Christian felt able to take on more of a leadership role amongst his peers. He also began to trust in his ability to provide support to other veterans suffering from post-traumatic distress, which led him to found the CVAF.

Shepherd Bliss believes that growing high-quality food for other people has been very important for him. "There was something about the recovery of the fruit that enabled my recovery," Shepherd said. Not only did he, through painstaking hard work, recover his farm from its previous state of disarray, he began to provide food - organic boysenberries and chicken eggs - to nourish the bodies and souls of others in his community. Furthermore, he takes on the role of guardian for his chickens, protecting them from predators such as mountain lions, coyotes, and great horned owls. Shepherd also has a prominent role as an advocate for the Farmer-Veteran Coalition, hosts other veterans on his farm, and recently began volunteering with the Horses Building Communities program in Sebastopol County, which uses equine therapy to support military men and women and their families at all stages.

When Gord Cousins was finally discharged from hospital after fifteen months of recovery, he was "in poor shape physically, skitterish, gun shy, under- weight." He believes the sudden transformation from being in the hospital to working in the bush in and around Thompson, Manitoba, for the summer was crucial to his recovery. "That immersion really rapidly put things behind me and I felt useful. It was the beginning of a feeling that I really had a role to play." And in the summers that followed, Gord continued to work outdoors. He recalls the experience of getting back into a canoe: "In each case, I was the bowman. I wasn't in charge of the canoe. But I was able to portage it and paddle and do the different strokes quite well."

In each of these cases, the veterans describe remembering skills and activities they had known prior to their military service, or had learned in the military but perhaps forgotten or not used recently. Andy Fisher observes that "our bodies ... still carry the knowledge of our buried needs, of our unactivated interactional patterns" [12, p. 109]. The areas and activities to which each veteran was drawn involved connecting with the wider world, rather than withdrawing inside himself. As each became immersed in the morethan-human world, and opened himself to that experience, his buried bodily needs became known. Most of the veterans described feeling separate from the human communities in which they were living, but as their bodies remembered previous roles, they, too, gained a purpose beyond the institutional context of the military. It was the wider world of nature that enabled them to once again connect with their own bodies, with other humans, and with the more-than-human world. Additionally, both Christian and Shepherd described how, at times, it is still difficult to be part of the human community, but in those instances, the wider planetary community - plants and animals in particular-provides the support to ground their lives in the present and carry their living forward.

\subsection{Relationships facilitated in more-than-human settings}

Social interaction is an important part of human experience, since as Fisher observes, "only a being who essentially belongs with others can suffer from isolation" [12, p. 78]. Hillman stresses how combat situations bring forth a tenderness and fellow-feeling amongst comrades. He recalls the words of a French soldier who wrote that his experience in the trenches was "the most tender human experience that he had ever enjoyed" [29, p. 147]. Hence, despite the violence and cruelty inherent in war, Hillman's words evoke a beauty in the ways that soldiers find community in 
fighting together - even in dying together. Indeed, the military is akin to a second family for most soldiers, and when a soldier leaves the military, it is comparable to leaving his/her family.

The experience of isolation is common amongst veterans suffering from post-traumatic distress, and during this research, several interviewees commented on the fact that many veterans spend a lot of time in their home basements. However, research indicates that stress and isolation are harmful to human health and can lead to slower healing and both magnify and multiply illness outcomes [6]. Judith Herman, clinical professor of psychiatry with expertise in trauma exposure, indicates that "disconnection from others" is a core experience associated with psychological trauma. And she observes that "recovery can take place only within the context of relationships; it cannot occur in isolation" [27, p. 133]. Similarly, Esther Sternberg observes that "positive social interactions are important buffers against stress" [6, p. 230]. Indeed, recent studies have shown the importance of social support in reducing rates of post-traumatic distress amongst those affected by war [45]. In line with this notion, in his interview, Kurt Hoelting reflected that the veterans who take his mindfulness-based stress reduction (MBSR) course get great benefit "from doing this work with others who have been where they are."

Similarly, the experiences of the veterans in this research reflect the significance of the social support and camaraderie facilitated within more-than-human settings. For example, psychiatrist Dr. Susan Brock, who leads an Operational Support Injury (OSI) clinic in Saskatoon, and who participated in the CVAF's 2009 weekend, wrote the following on the group's website:

Avoidance, withdrawal, and social isolation are often the most treatment resistant symptoms of PTSD, and the hardest to challenge within a traditional therapy setting ... It was a truly rewarding experience as a therapist to witness first-hand the transformation that occurred in this group over the course of the weekend; anxiety transformed into smiles and expressions of joy [40].

As Andy Fisher described, it is simply a phenomenological fact that being in the natural world opens human beings to the possibility of making good contact with one another at the level of their shared experience. He suggested an analogy to the ways that nature provides a secure base from which we can feel safe enough to make contact with others in a supportive way. And each of the veterans' narratives provides ex- amples of how it is this collective experience that supports veterans in helping one another. Indeed, Christian McEachern's whole purpose in starting the CVAF was to provide support for other veterans who, like him, were suffering from post-traumatic distress. And he described how on the first morning of rafting together as a group, the veterans on the CVAF's 2009 summer program began to visibly relax. Tim Normann reflected that in his experience, when soldiers and veterans come together in the outdoors, their conversations often turn to their post-military experiences of anger and hypervigilance, which provides them with insight and understanding into the ways they have been changed by their military service. While Shepherd Bliss observed that farming can provide solitude when a veteran needs it, he also described how veterans can sit together and find comfort in one another's experiences and stories, both on his farm around the picnic table as well as in the Veterans' Writing Group to which he belongs. And Gord Cousins described how it was first volunteering for the Cadets in the 1990s and then being invited to reenlist into the Reserves - his old family - that gave him a new sense of purpose and increased time outdoors, which also coincided with reduced angry outbursts and better sleeping.

French phenomenologist Maurice Merleau-Ponty brings attention to the fact that "we do not start out in life immersed in our own self-consciousness (or even in that of things) but rather from the experience of other people" [46, p. 65]. He argues that it is only through contact with others that we come to be aware of and understand our own existence. And it is this common understanding and contact with others that seems particularly important in the veterans' experiences. As Tim Normann emphasized, in his experience the more-than-human world facilitates interactions that do not happen within more urban or indoor contexts. However, Kurt Hoelting highlights that through mindfulness practice, changes can and do occur, even in bleak contexts such as the hospital basement where he teaches MBSR classes for veterans. He observed that our inner human nature makes sure that we can connect with one another in any environment, but that being in a natural setting facilitates the process.

Robert Greenway recalls that human evolution took place in a tribal setting, in which mutual care and sharing essential activities were important for the very survival of the human species. He argues that spending time together in nature, particularly in situations that require mutual trust and care, "arouse this tribal consciousness" [7, p. 136]. In addition, Fisher writes 
that "any practice that helps re-embed us within the society of nature, or expand the field of our care, cannot but help us bear our pain and suffering" [12, p. 192]. Fisher's reflection is borne out in both Christian McEachern's and Shepherd Bliss's descriptions of the importance of more-than-human beings in their lives. For Christian, who has often felt isolated since leaving the military, his dogs and his horse have provided crucial companionship. Further, Christian's good friend Monica Culic observed that he has become more grounded and aware of his reactions through spending time with and caring for his horse, which she implied has also helped his relationships with other people. And throughout his interview, Shepherd referred often to animals and insects. When he recalls the time spent on his uncle's farm during his youth, Shepherd fondly remembers making good contact with the animals and bees there. On his own farm today, he loves to watch his chickens dance and play and maintains that they have something important to teach him.

\section{Discussion}

A sense of lost humanity is common amongst those who have lived in the midst of violence and conflict. In Judy Jackson's film War in the Mind, Wayne, a young veteran, observed that "being a basic human being conflicts with being a soldier in some circumstances. Because you know as a human being what you should be doing, but as a soldier, it may be different" [47]. Meanwhile, Morris, the former Sierra Leonean child soldier, noted that no longer feeling human led him to escape from his former life [2]. And as Lt. Gen. Roméo Dallaire stood on that hilltop in Rwanda, his very words were, "C'est ici que j'ai redevenu humain" ("It's here that I became human again") [1].

Indeed, when hearing and reading accounts of soldiers in training and combat, one realizes that the training and the actual act of being a soldier can narrow a person's sense of humanity. The UBC Veteran's Transition Program director, Dr. Marvin Westwood, told Jackson that part of the purpose of his program is to "undo the wiring that military training has implanted in [the veterans'] brain" [47]. And Christian McEachern, Tim Normann, Gord Cousins, and Shepherd Bliss all spoke about their military training and/or upbringing as influential in their lives. While each described gaining skills and a sense of discipline, this training, which included sleep deprivation, being marched around to the point of exhaustion, being constantly yelled at, and being taught to respond with speed, aggression, and violence, also involved learning to suppress or ignore his body's instincts. As Jungian psychoanalyst James Hillman reflects, "The eventual unbearable division between the engine of war and human warrior commences in the drills learned in basic training performed as ceremonies of separation" [29, p. 63].

All the themes explored in this paper culminate in the notion that contact with more-than-human nature provides possibilities for regaining one's lost sense of humanity. Fisher suggests that when we, as human beings, are alienated from our body's naturalness, our body is in conflict with itself. He describes how "kinship with the rest of nature has traditionally been won by admitting boundaries and then dialoguing with the nonhuman presences on the other side of them, through ritual, dream, myth, nonordinary states of consciousness, skillful everyday interaction, and so forth" [12, p. 96].

It is perhaps important to ask: What is it to be human? The etymological origins of the word 'human,' the Latin humus, point to the literal meaning that humans are 'of the earth, soil or ground' [41]. Similarly, the Hebrew word for 'man,' adam, comes from the Hebrew adamah, meaning 'ground.' Connected to the earth and soil, human bodies and minds are inseparable from the sensible world. As Merleau-Ponty observed, "There is no break in this circuit; it is impossible to say that nature ends here and that man or expression starts here" [48, p. 319]. The Western habit of mind, however, resists this insight, since the separate self is a defining feature in our individualistic worldview. As Catherine Keller observed in an interview with Derrick Jensen, "one of the prime hallucinations of Western culture - and I would add the paradigm of dominance is the belief that who you are is a skin-encapsulated ego" [49, p. 274].

Amongst the symptoms associated with post-traumatic distress are feelings of isolation, loneliness, and helplessness, resulting in increasingly avoidant behaviour, a disengagement from the outside world, and an overwhelming sense of being able to do nothing [50-52]. A movement toward humanity, on the other hand, implies the opposite of feeling alone and isolated. It suggests moving outside oneself, an engagement and relationship with others and with the world. A restored sense of humanity thus implies coming back to participation in the (more-than-human) world, for as David Abram observes, "We are human only in contact, and conviviality, with what is not human" [53, p. 22]. 
The movement from aloneness to humanity is vivid in all the stories in this research. Christian McEachern started the CVAF with the specific intent of working with other veterans suffering from post-traumatic distress. Shepherd Bliss hosts other veterans on his farm and is involved in community programs for soldiers, veterans and their families, such as Horses Building Communities and the Farmer Veteran Coalition. And Tim Normann and Gord Cousins are also active with reaching out to other soldiers and veterans. In each of the stories shared in this paper, it was intimate embodied contact with more-than-human nature that reimbued life with new or remembered meaning. That contact helped the veterans remember they are anchored to the world and begin to make sense of their experiences. It seems, perhaps, that it is only in contact and deep relationship with the natural world that we are most human.

During his interview, Kurt Hoelting reflected on the moment on his kayak retreats when participants move beyond their intellectual understanding of nature and realize that "at a cellular or visceral level, we're part of something really huge." Kurt described this experience as catalytic for participants. Similarly in the veterans' narratives of recovery, one can appreciate their realization that the more-than-human world is deeply implicated in their own life and experience. The veterans' stories point clearly to an understanding through their bodies that nature is a place they feel secure and that it is in contact with the wider world that they find hope and possibilities for carrying their human living forward. Each in their different ways, the veterans are describing their innate desire - perhaps both conscious and unconscious - to go beyond human communities and to connect with more-than-human nature.

Each veteran's body is expressing its need to connect to the larger world, which is demonstrated by the shift in their experiences when they spend time in nature [30]. There is an overwhelming sense of presence, mindfulness, and awareness in each narrative, as well as the calmness and peace that comes with that experience. Perhaps the veterans are describing what Kurt Hoelting remarked is "the boundary between self and world softening," the ways that the heart and mind can open more easily and quickly in nature.

In suggesting that more-than-human nature is important for soldiers and veterans recovering from stress and post-traumatic distress, contact with nature is not advocated as a panacea to cure all ills. Connelly and Clandinin warn about the danger of a "Hollywood plot" in narrative inquiry, where participants' stories are smoothed and moulded by the researcher to show that despite hardships, everything worked out and ended well [32]. It is important to remember that the stories told by Christian McEachern, Tim Normann, Gord Cousins, and Shepherd Bliss are the narratives they continue to inhabit every day. Their experiences in nature have not "cured" their stress and/or posttraumatic distress, and all spoke of their need for more than one path of recovery. For Christian, in addition to spending as much time as possible in the outdoors and with his animals, the path has involved medication and therapy. Tim eventually sought counselling to gain further insight into his post-military stress reactions. Gord believes that re-enlisting in the Reserves and once again having a larger purpose in life was important for his own recovery. And Shepherd's involvement in the Veterans' Writing Group has been a crucial part of his healing, in addition to individual and group therapy over the years.

Accordingly, connecting with nature does not in itself guarantee transformation or healing and recovery, and nature contact is not a cure-all or magic treatment for veterans. Many veterans continue to benefit from medication and therapy, but find that nature provides an additional measure of support, relief and healing in their lives.

\section{Conclusion}

Other veterans describe experiences similar to those detailed in this research [54]. Canadian scholar, Harold Adams Innis, who was wounded in World War I, undertook a summer-long canoe trip on the Peace and Slave Rivers in 1924 with his friend John Long. Innis's biographer Donald Creighton writes that "the long summer, with its wind and sun, its space, and peace, and friendly companionship, had done [Innis] an immense amount of good. He had, as it were, shaken off the last of the evil effects of the war ... He had recovered his health and spirits" [55, p. 63]. Similarly, during World War II, American psychiatrist Karl Menninger became the first advocate for horticulture therapy to help U.S. veterans recover from their wartime experiences [5,56,57].

Today, there is a growing movement to provide opportunities for U.S. veterans to move into farming after they leave the military. These soldiers-turned-farmers, many of whom suffer from stress and/or post-traumatic distress, are reporting significant benefits from working outdoors with plants and animals and providing 
healthy foods to feed other people [58-63]. Many of these farmers also offer peer-to-peer programs for other wounded veterans, who come to work on their farm, decompress, and explore farming as a possible career. The overall commonality amongst the different farms and programs is that the soldiers-turned-farmers are describing how farming has showed them the way forward - the ways that life can continue beyond their military experiences [58-63].

The veterans' narratives in this research give space to the former soldiers' personal experiences and to their realizations that their embodied interconnections within more-than-human nature provide alternative experiences to their military training and combat exposure. The rhythms of the more-than-human world become part of and leave traces on each person's story. Nature speaks through the veterans' bodies and through their stories of embodied experience as they come into relationship with one another and with the natural world. The importance of paying attention to these stories of experience is that while they are few in number, one cannot deny that the experiences are pointing toward an avenue of recovery that is little acknowledged in the mainstream literature and praxis. As Andy Fisher observed during his interview, when a veteran describes the shift in his experience in nature, this "takes our thinking of the healing process beyond the therapy office into a more-than-human field of what might be called for in the healing process."

\section{References}

[1] Raymont P, director and producer. Shake hands with the devil: The journey of Roméo Dallaire [Film]. Canadian Broadcasting Corporation, White Pine Pictures, Société Radio Canada, 2004.

[2] Lederach JP, Lederach AJ. When blood and bones cry out: journeys through the soundscape of healing and trauma. Oxford: Oxford University Press, 2010.

[3] Searles HF. The nonhuman environment: In normal development and in schizophrenia. New York: International Universities Press, Inc., 1960.

[4] Roszak T. The voice of the earth: An exploration of ecopsychology. 2nd ed. Grand Rapids: Phanes Press Inc.; 2001.

[5] Louv R. Last child in the woods: Saving our children from nature-deficit disorder (updated and expanded). Chapel Hill (NC): Algonquin Books of Chapel Hill, 2008.

[6] Sternberg EM. Healing spaces: the science of place and wellbeing. Cambridge (MA): The Belknap Press of Harvard University Press, 2009.

[7] Greenway R. The wilderness experience as therapy: we've been here before. In: Buzzell L, Chalquist, C, editors. Ecotherapy: healing with nature in mind. San Francisco: Sierra Club Books, 2009, p. 132-139.
[8] Messer Diehl ER. Gardens that heal. In: Buzzell L, Chalquist, C, editors. Ecotherapy: healing with nature in mind. San Francisco: Sierra Club Books, 2009, p. 166-173.

[9] Pretty J. How nature contributes to mental and physical health. Spirituality and Health International. 2004; 5(2): 6878.

[10] Di Iacovo F, O'Connor D, editors. Supporting policies for social farming in Europe: progressing multifunctionality in responsive rural areas. Sesto Fiorentino (FI): Press Service srl; 2009 [cited 2012 Oct 25]. Available from: http://sofar. unipi.it/index_file/arsia_So.Far-EU_def.pdf.

[11] Roszak T. The nature of sanity. Psychology Today. 1996; 29(1): 22-24

[12] Fisher A. Radical ecopsychology: psychology in the service of life. Albany, NY: State University of New York Press, 2002.

[13] Besthorn FH, Wulff D, St. George S. Eco-spiritual helping and postmodern therapy: A deeper ecological framework. Ecopsychology. 2010; 2(1): 23-32.

[14] Hillman J. A psyche the size of the earth: A psychological foreword. In Roszak T. Gomes M, Kanner A, editors. Ecopsychology: restoring the earth, healing the mind. San Francisco: Sierra Club Books, 1995, p. xvii-xxiii.

[15] Glendinning C. Technology, trauma, and the wild. In Roszak T. Gomes M, Kanner A, editors. Ecopsychology: Restoring the earth, healing the mind. San Francisco: Sierra Club Books, 1995, p. 41-54.

[16] Robinson L. Psychotherapy as if the world mattered. In: Buzzell L, Chalquist C, editors. Ecotherapy: healing with nature in mind. San Francisco: Sierra Club Books, 2009, p. 2429.

[17] Wilson EO. Biophilia: The human bond with other species. Cambridge (MA) and London (England): Harvard University Press, 1984.

[18] Wilson EO. Biophilia and the conservation ethic. In: Kellert SR, Wilson EO, editors. The biophilia hypothesis. Washington, DC: Island Press, 1993, p. 31-41.

[19] Goleman D. Ecological intelligence: the hidden impacts of what we buy. New York: Broadway Books, 2010.

[20] Gardner H. Frames of mind: the theory of multiple intelligences. New York: Basic Books, 1983.

[21] Lambert K. Lifting depression: A neuroscientist's hands-on approach to activating your brain's healing power. New York: Basic Books, 2008.

[22] Lakoff G, Johnson M. Philosophy in the flesh: The embodied mind and its challenge to Western thought. New York, NY: Basic Books, 1999.

[23] Smith EO. When culture and biology collide: why we are stressed, depressed and self-obsessed. New Brunswick, NJ: Rutgers University Press, 2002.

[24] Tick, E. War and the soul: healing our nation's veterans from post-traumatic stress disorder. Wheaton (Il): Quest Books, 2005.

[25] Tanielian T, Jaycox LH, editors. Invisible wounds of war: psychological and cognitive injuries, their consequences, and services to assist recovery. Santa Monica (CA): RAND, 2008.

[26] Alexander C. The shock of war: World War I troops were the first to be diagnosed with shell shock, an injury - by any name - still wreaking havoc. Smithsonian Mag. 2010 [cited 2012 Oct 25]; 41(5). Available from: http://www.smithsonian mag.com/history-archaeology/The-Shock-of-War.html?c=y\& story=fullstory.

[27] Herman JL. Trauma and recovery: The aftermath of violence - from domestic abuse to political terror. New York: Basic Books, 1997. 
[28] Singer M. Transforming the trauma of war in combat veterans. In: Bussey M, Wise JB, editors. Trauma transformed: An empowerment response. New York: Columbia University Press, 2007, p. 259-278.

[29] Hillman J. A terrible love of war. New York: The Penguin Press, 2004.

[30] Fisher A. To praise again: phenomenology and the project of ecopsychology. Spring Journal 2006; 75: 153-174.

[31] Etherington K, editor. Trauma, the body and transformation: A narrative inquiry. Philadelphia, USA: Jessica Kingsley Publishers, 2003.

[32] Connelly FM, Clandinin DJ. Narrative inquiry: Storied experience. In: Short EC, editor. Forms of curriculum inquiry. Albany: State University of New York Press, 1991, p. 121-153.

[33] Creswell JW. Educational research: planning, conducting, and evaluating quantitative and qualitative research. 4th ed. Boston: Pearson Education, Inc.; 2012.

[34] Schaafsma D, Vinz R. On narrative inquiry: approaches to language and literacy research, an NCRLL volume. New York: Teachers College Press, 2011.

[35] Squire C. Experience-centred and culturally oriented approaches to narrative. In Andrews M, Squire C, Tamboukou $\mathrm{M}$, editors. Doing narrative research. London: SAGE Publications Ltd., 2008, p. 41-63.

[36] Jung H (Captain). Can the Canadian Forces reflect Canadian society? Canadian Military Journal 2007; 8(3): 27-36.

[37] Beatley T. Green urbanism: learning from European cities. Washington, DC: Island Press, 2000.

[38] Bliss S. In praise of sweet darkness. In: Buzzell L, Chalquist C, editors. Ecotherapy: Healing with nature in mind. San Francisco: Sierra Club Books, 2009, p. 174-184.

[39] Bliss S. Farms heal - agrotherapy [Internet]. [Place unknown]: Countercurrents.org; 2009 [cited 2012 Oct 25]. Available from: http://www.countercurrents.org/bliss020209. htm.

[40] CVAF Guest Book [Internet]. Calgary: Canadian Veteran Adventure Foundation, 2009 [cited 2012 Oct 25]. Available from: http://www.canadianveteranadventurefounda tion.com/Guest-Book.html.

[41] OED [Internet]. Online Etymology Dictionary. [Place unknown]: Douglas Harper; 2012. Available from: http://etymon line.com.

[42] Goffman E. Asylums: Essays on the social situation of mental patients and other inmates. Chicago: Aldine Publishing Company, 1962.

[43] Goldstein JS. War and gender. Cambridge: Cambridge University Press, 2001.

[44] Taber N. Ruling relations, warring, and mothering: writing the social from the everyday life of a military mother. Saarbrucken, Germany: Lambert Academic Publishing, 2011.

[45] Ahern J, Galea S, Fernandez WG., Koci B, Waldman R, Vlahov D. Gender, social support, and posttraumatic stress in postwar Kosovo. J. of Nervous and Mental Dis. 2004; 192(11): 762-70

[46] Merleau-Ponty M. The world of perception. (Oliver Davis, trans.). London and New York: Routledge Classics, 2004.
[47] Jackson $\mathrm{J}$, director and producer. War in the mind [Film]. TVO: Judy Films BC Inc; 2011. Available from: http://docs tudio.tvo.org/story/war-mind.

[48] Merleau-Ponty M. Eye and mind (Carleton Dallery, trans.). In: Baldwin T, editor. Maurice Merleau-Ponty: Basic writings. New York: Routledge, 2004, p. 290-324.

[49] Keller C. Catherine Keller (interview). In: Jensen D, editor. Listening to the land: conversations about nature, culture, and eros. Albany: State University of New York Press, 2002, p. 273-281.

[50] Benedek DM. Posttraumatic stress disorder from Vietnam to today: the evolution of understanding during Eugene Brody's tenure at the Journal of Nervous and Mental Disease. J. of Nervous and Mental Dis. 2011; 199(8): 544-552.

[51] Hewson M. Horticultural therapy and post traumatic stress recovery. J. of Therapeutic Horticulture. 2001; XII: 44-47.

[52] Lamprecht F, Sack M. Posttraumatic stress disorder revisited. Psychosometric Medicine. 2002; 64(2): 222-237.

[53] Abram D. The spell of the sensuous: Perception and language in a more-than-human world. New York: Vintage Books; 1996.

[54] Westlund S. Field exercises: How veterans are healing themselves through farming and outdoor activities. Gabriola Island, BC: New Society Publishers, 2014.

[55] Creighton D. Harold Adams Innis: Portrait of a scholar. Toronto: University of Toronto Press; 1957.

[56] Lewis CA. Green nature/human nature: The meaning of plants in our lives. Urbana: University of Illinois Press; 1996.

[57] Relf PD. Agriculture and health care: the care of plants and animals for therapy and rehabilitation in the United States. In Hassink J, van Dijk, M, editors. Farming for health: greencare farming across Europe and the United States of America. Dordrecht: Springer, 2006, p. 309-343.

[58] Archi's Acres. About Archi's Acres [Internet]. California: Archi's Acres [date unknown], [cited 2012 Oct 25]. Available from: http://archisacres.com/page/about.

[59] Brown PL. Helping soldiers trade their swords for plows. New York Times; 2011 Feb 5. [cited 2012 Oct 25]. Available from: http://www.nytimes.com/2011/02/06/us/06vets.html?_r=1\& pagewanted=all.

[60] Seymour B, producer. Vets' Garden, Westwood; Westwood (CA): [publisher unknown]; 2009. Available from: http:// www.youtube.com/watch?v=eir1hzvAX-0\&feature=related.

[61] Shooting Star CSA [Internet]. Fairfield (CA): Shooting Star CSA; [date unknown], [cited 2012 Oct 25]. Available from: http://www.shootingstarcsa.com/.

[62] Farmer Veteran Coalition. Veterans Farm gets new land, issues press release [Internet]. Davis (CA): Farmer Veteran Coalition; 2010 April 23. [Cited 2012 Oct 25]. Available from: www.farmvetco.org/veterans-farm-gets-new-landissues-press-release.

[63] Veterans Farm [Internet]. Jacksonville (FL): Veterans Farm; 2012 [cited 2012 Oct 25]. Available from: http://veterans farm.com. 